\title{
PREVALENCE OF MALARIA, TYPHOID AND CO-INFECTION IN DISTRICT DIR (LOWER), PAKISTAN
}

\author{
PREVALÊNCIA DE MALÁRIA, FEBRE TIFÓIDE E CO-INFECÇÃO NO DISTRITO \\ DIR (INFERIOR), PAQUISTÃO
}

\section{Asma Waheed QURESHI ${ }^{1}$; Zaib-ullah KHAN ${ }^{2}$ Luqman KHAN $^{* 3}$; Abu MANSOOR ${ }^{2}$; Rashid MINHAS ${ }^{2}$}

1. Department of Zoology, Government College Women University, Sialkot; Pakistan 2. Department of Zoology, Abdul Wali Khan University Mardan, Khyber Pakhtunkhwa, Pakistan; 3. Graduate School of Life Sciences, Tohoku University, Japan.* luqman.zoology@gmail.com; asmawqureshi@yahoo.com

\begin{abstract}
Malaria and typhoid fever are among the most endemic diseases in the tropical and developing countries. Both diseases share similar transmission factor and often have the similar symptom. Based on this reason, much medical personnel try to cure both malaria and typhoid instantaneously in each case of suspected Salmonella infection and vice versa. The District Dir (Lower) is a favorable location for the protozoan nourishment and secondly mostly reported cases of malaria and typhoid co-infections. The main objective of this study was to find out the prevalence of malaria and typhoid co-infection in the District Dir (Lower), Khyber Pakhtunkhwa (KPK), Pakistan. The blood samples of 1889 patients were examined from September 2012 to April 2013, out of which 311 (16.46\%) were positive for malaria and typhoid. Out of these infected, 117 (38\%) sample was positive for malaria, 183 (58\%) sample were positive for typhoid while coinfected cases were only $11(4 \%)$. The current results indicate that this area is endemic for malaria and typhoid and co-infection. Its infection is prevalent in both the genders at varying degrees.
\end{abstract}

KEYWORDS: Malaria. Typhoid. Co-infection. KPK.

\section{INTRODUCTION}

Malaria and typhoid fever persist the infections of main public health significance and source of illness and transience in the tropics (UNEKE, 2008). Both diseases are communal in various nations of the world wherever the prevailing ecological environments of warm tropical temperature, poor hygienic practices, poverty, and ignorance be present. These two infections have been concomitant with poverty and underdevelopment.

Malaria is a parasitic disease caused by four protozoan parasites in human known as $P$. falciparum, $P$. vivax, $p$. malariae, $P$. knowlesi (ORGANIZATION, 2010). The most important species in genus Plasmodium is P. falciparum which causes great mortality in all over the world (KOCHAR et al., 2014). Malaria is a major health problem in tropical areas and in developing countries (HALLIDAY et al., 2015). Malaria is transferred to human through a female Anopheles' mosquito (WANG; JACOBS-LORENA, 2017). During malaria hematological and biochemical changes take place due to which the infection become more severe (KREMSNER et al., 2016). White blood cell (WBC) count remains constant while lactate dehydrogenase increases in malarial patients. During malaria fever rise quickly increase up to $38.9^{\circ} \mathrm{C}$ to $41^{\circ} \mathrm{C}$. Chill fever is followed by diaphoresis and malaise (WOODRUF; WRIGHT, 2013).

Malaria is infectious disease that causes 300 to 500 infections and 2 to 3 million death annually (NIIKURA et al., 2010). Malaria is mostly a great health problem in Asia, Latin America, Middle East, Eastern Europe and Africa. About 90 percent of malarial cases are recorded in south Sahara of Africa. In Bangladesh the malarial situation is deteriorating since 1980 (ONIS et al., 2000). Brazil is worst affected, where about $50 \%$ of malarial patient is found and about 6000 to 10000 die annually (FERNANDES ET AL., 2008). Some country of the world like Afghanistan where about 300000 malarial cases were recorded due to civil war and internal displacement. In the same way in Sierra leon where health staff is displaced and health facilities reduced due to war, in the result of which half patient of the total is malarial (ORGANIZATION, 2010). In the East Mediterranean region, the dominant species of malaria is $P$. falciparum. According to United Nation World Health Organization (WHO) Pakistan is the country with moderate malaria prevalence (CULlEN; ARGUIN, 2014). Among Plasmodium species Plasmodium falciparum are the widespread 
specie in Pakistan which causes about 36\% of infections (RAFIQUE et al.). In Pakistan about 3.6 million slide were prepared in 2006 for malarial diagnosis in which about 127,825 cases of malaria were confirmed. The actual cases load will be very high because some diagnosis center does not maintain the record of patient. While in 2004 the estimated cases in Pakistan is 1.5 million (YASINZAI; KAKAR, 2012). In 2004 in Punjab and Azad Jammu Kashmir the malarial incidence was lower, while in Baluchistan and FATA the malarial incidence was high and in Khyber PakhtoonKhwa and in Sindh the cases were moderate (YASINZAI; KAKAR, 2012). The cerebral malaria is more in male (64\%) in Khyber PakhtoonKhwa (YASINZAI; KAKARSULEMANKHEL, 2013). Falciparum malaria is mostly found in Afghan refugees in KPK (ZAREEN et al., 2016).

While typhoid fever is a systematic and infectious fever of global distribution (MOGASALE et al., 2014). In human typhoid is cause by Salmonella enterica serotype (S. Typhi) or ( $S$. paratyphi) (WONG et al., 2016). Salmonella typhi can survive in fresh, salty and brackish water for several weeks and can multiply in milk products (EKESIOBI et al., 2017). Flies and other insect transfer infective microbe from infected feces and other material to drink and food (ZUREK; GHOSH, 2014).

Typhoid symptoms are headache, high, fever, malaise, nausea and abdominal pain (COLOMBA et al., 2016). Other complication is intestinal perforation pneumonia and myocarditis (SULAIMAN; SARWARI, 2007). About 17 million typhoid cases are reported each year (KEONG; SULAIMAN, 2006). The most endemic region of the world for typhoid is Indian sub-continent, South East Asia, Africa, Middle East, South and Central America where clean water and sewage control are inadequate (ARAFAT et al., 2014). It is estimated that more than 13 million cases of typhoid occur only in Asia annually in which a large proportion is found in children (CONNOR; SCHWARTZ, 2005). Due to the limitation of national surveillance system for infectious disease population based data for typhoid fever are not available in Pakistan. But the local epidemiological studies have shown high typhoid fever incidence in young children (FAROOQUI et al., 2009). The incidence of typhoid fever is 412 cases per 100,000 populations per year in Pakistan (ACOSTA et al., 2008).

An association between malaria and typhoid fever was first described in the middle of $19^{\text {th }}$ century and was named as Typo malarial fever by the United States Army. However, in the end of $19^{\text {th }}$ century the developed laboratory test rejects this theory, because they found that it was either one thing or other or in rare instance it is co-infection with both Salmonella typhi and the Plasmodium species (RAO; SOWMYA, 2015). Although, malaria and typhoid is caused by two different organisms in which one is protozoan and other is gram negative bacilli, which transmit by two different mechanisms and both disease share similar symptomology, because both typhoid and malaria share social circumstances which are important for their transmission (RAO; SOWMYA, 2015). The People living in the area which are endemic for both typhoid and malaria are at risk of getting disease either concurrently or acute infection superimpose the chronic one (ACHONDUH-ATIJEGBE et al., 2016). So the mimicking and same symptomology of typhoid and malaria often present a diagnostic problem which lead to diagnostic confusion. So before the individual is said to have concurrent malaria and typhoid fever, the presence of Plasmodium and Salmonella enterica sub-species enteric serotype typhi must be demonstrated in the patient laboratory specimen (ODIKAMNORO et al., 2018).

This study was carried out to determine the prevalence of malaria and typhoid co-infection in the District Dir (Lower), Khyber Pakhtunkhwa (KPK), Pakistan. The District Dir (Lower) has favorable conditions for the protozoan parasites and mostly reported cases of malaria and typhoid coinfections.

\section{MATERIAL AND METHODS}

\section{Study Area}

Overall population of District Lower Dir is 1.436 million. The samples were collected from the District Headquarter Hospital Timergara, Khyber Pakhtunkhwa (KPK), during the period of September 2012 to April 2013, where the patient was directed by the medical Physician to the laboratory for the routine Typhoid and Malarial tests having symptoms for these infections. 


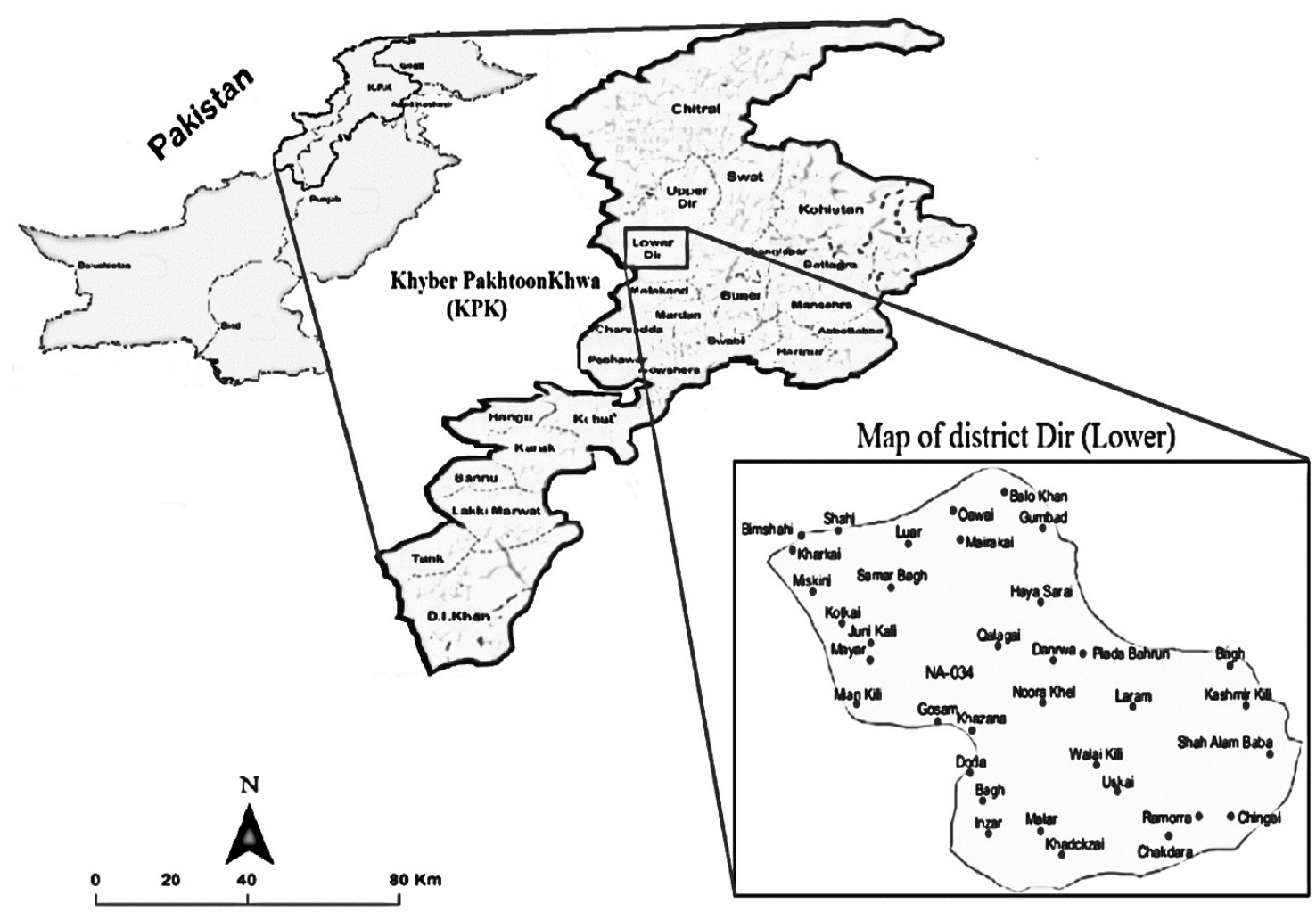

Figure 1. Map of District Dir (Lower), Khyber Pakhtunkhwa Pakistan

\section{Exclusive Criteria}

Patients with any other bacterial or parasitic infections were excluded from the study to reduce the chance of false positive results. Children less than 1 year age were also excluded from study.

\section{Sample Collection}

The blood samples were collected from the affected individuals after informed consent. Three milliliters $(3 \mathrm{ml})$ of blood sample was collected from each patient into sterilized EDTA ${ }^{\circledR}$ falcon tube by the trained phlebotomist.

\section{Malarial Diagnosis}

A drop of blood was placed at the center of grease free slide with the aid of applicator stick. The Giemsa-stained thin blood films were prepared for each sample. The films were examined microscopically for the presence of malarial parasite within red blood cell in thin films. While in thick films the ring forms trophozoites and gametocytes looked for. A smear was considered negative for malaria parasite, if there were no parasite present while examining on 100x microscopic field. The number of parasite per micro litter of blood was expressed as (parasite count $X$ 5400)/number of leucocytes counted which was 100 (ALHASSAN et al., 2012).

\section{TYPHIDOT Rapid IgG AND IgM Rapid Test for Detection of Typhoid Fever}

The Typhidot rapid IgG and IgM is an indirect solid phase immuno chromatographic assay. The specific Salmonella typhi antigen is immobilized onto cellulose nitrate membrane strip. By the addition of test sample to the sample pad it migrates upward. If in the serum antibodies against Salmonella typhi is present so it will form antigen antibody complex with the immobilized antigen at the test window zone. These complexes are detected by a dye conjugated goat anti human IgM by adding chase buffer which give to it a pink-purplish color. The control line contains rabbit anti goat IgG antibody which bind with dye conjugated goat antihuman IgM. The control band serves as indication of proper migration plus reagent control (LEVINE et al., 1978).

\section{Ethical Aspects}

All samples were collected after taking written consent of patients and after approval of Ethical Review committee of Abdul Wali Khan University, Mardan.

\section{Statistical analysis}

The data was analyses statistically by using Chi square $\left(\chi^{2}\right)$ by using SPSS. 


\section{RESULTS}

\section{Overall Prevalence (\%)}

During the study period out of 1889 , a total of $311(16.46 \%)$ infected cases were found positive for malaria and typhoid in District Hospital Timergara Dir Lower. In these 311 total infected cases, 117 patients were positive for malaria, which were about $38 \%$ of the total cases and 183 cases were positive for Typhoid, which were about 58\% of the total infected cases. The co-infected cases for both malaria and typhoid were 11 which is $4 \%$ of the total infection. Statistically co-infection of typhoid and malaria is significantly low $(\mathrm{P}<0.01)$ than two infections separately (Table 1).

Table 1: Overall prevalence (\%) of Malaria, Typhoid \& Co. infection

\begin{tabular}{llllllll}
\hline $\begin{array}{l}\text { Total } \\
\text { samples }\end{array}$ & $\begin{array}{l}\text { Total } \\
\text { infected } \\
\text { samples }\end{array}$ & $\begin{array}{l}\text { No. of } \\
\text { Malaria } \\
\text { +ve }\end{array}$ & $\begin{array}{l}\text { Prevalence } \\
(\%)\end{array}$ & $\begin{array}{l}\text { No. of } \\
\text { Typhoid } \\
\text { +ve }\end{array}$ & $\begin{array}{l}\text { Prevalence } \\
(\%)\end{array}$ & $\begin{array}{l}\text { No. of Co- } \\
\text { infected }\end{array}$ & $\begin{array}{l}\text { Prevalence } \\
(\%)\end{array}$ \\
\hline 1889 & 311 & 117 & 38.0 & 183 & 58.0 & 11 & $4.0^{* *}$
\end{tabular}

Statistical analysis: ** $\mathrm{P}<0.01$

\section{Age Wise Prevalence (\%)}

For the age wise prevalence, we have taken two groups in which one group was of children (112 year) and other was of adult (13-60year). In the total malarial infected cases children were $57 \%$ and adults were $43 \%$. The total typhoid cases were 183 in which children were $60 \%$, while adult were $40 \%$. The co-infected cases of Typhoid and Malaria were 11 in all the infected cases, in which $55 \%$ cases were found in children and $45 \%$ cases were found in adult (Table 2). There was no significant difference between age wise prevalence $(\mathrm{P}>0.05)$.

Table 2. Age wise prevalence (\%)

\begin{tabular}{llllll}
\hline Factor & $\begin{array}{l}\text { No. of total } \\
\text { Infected sample }\end{array}$ & $\begin{array}{l}\text { No of Infected } \\
\text { Children } \\
(\mathbf{1 - 1 2} \text { year) }\end{array}$ & $\begin{array}{l}\text { Prevalence } \\
(\%)\end{array}$ & $\begin{array}{l}\text { No of Infected } \\
\text { Adults } \\
(\mathbf{1 3 - 6 0} \text { year) }\end{array}$ & $\begin{array}{l}\text { Prevalence } \\
\text { (\%) }\end{array}$ \\
\hline Malaria & 117 & 67 & 57.0 & 50 & 43.0 \\
Typhoid & 183 & 110 & 60.0 & 73 & 40.0 \\
Co-infection & 11 & 6 & 55.0 & 5 & 45.0 \\
\hline
\end{tabular}

\section{Gender Wise Prevalence (\%)}

In the total malarial cases which are (117), $56 \%$ cases were positive for male and $44 \%$ cases were positive for female. In the total (183) typhoid cases $51 \%$ cases were positive for male while $49 \%$ cases were positive for female. The co-infected cases for malaria and typhoid were 11 in which $55 \%$ cases were found in male while $45 \%$ cases were found in female (Table 3). There was no significant difference between male and female infections $(\mathrm{P}>0.05)$.

Table 3. Gender wise prevalence $\%$.

\begin{tabular}{cccccc}
\hline Factor & $\begin{array}{c}\text { Total Infected } \\
\text { sample }\end{array}$ & $\begin{array}{c}\text { Number of } \\
\text { infected Males }\end{array}$ & $\begin{array}{c}\text { Prevalence } \\
(\mathbf{\%})\end{array}$ & $\begin{array}{c}\text { Number of } \\
\text { infected } \\
\text { Females }\end{array}$ & $\begin{array}{c}\text { Prevalence } \\
(\%)\end{array}$ \\
\hline Malaria & 117 & 65 & 56.0 & 52 & 44.0 \\
Typhoid & 183 & 93 & 51.0 & 90 & 49.0 \\
Co-infection & 11 & 6 & 55.0 & 5 & 45.0 \\
Total & $\mathbf{3 1 1}$ & $\mathbf{1 6 4}$ & $\mathbf{5 3 . 0}$ & $\mathbf{1 4 7}$ & $\mathbf{4 7 . 0}$
\end{tabular}




\section{Month Wise Prevalence (\%)}

During the different months the prevalence of different infections were different. In September the total infected cases were 83 in which malarial cases were $42 \%$, typhoid was $53 \%$ while co-infected cases of malaria and typhoid were $5 \%$. In October the total infected cases were 57 in which $47 \%$ cases were positive for malaria, $49 \%$ cases were positive for typhoid while co-infected cases were $4 \%$. In the month of November, the total infected cases were 31 in which $29 \%$ cases were positive for malaria, $68 \%$ cases were positive for typhoid and only $3 \%$ case was co-infected with both for malaria and typhoid. In December the total cases were 17 in which $12 \%$ cases were positive for malaria, $88 \%$ cases were positive for typhoid while co-infection were $0 \%$. In January the total infected cases were 19 in which there was $0 \%$ malaria, co-infected cases were also $0 \%$ while $100 \%$ cases were positive for typhoid. In February the total infected cases were 10 in which $20 \%$ cases were positive for malaria and $80 \%$ cases were positive for typhoid while coinfected cases were $0 \%$. In March the total infected cases were 33 in which $33 \%$ cases were positive for malaria, $64 \%$ cases were positive for typhoid and the co-infected cases were 3\%. In April the total infected cases were 61 in which $51 \%$ cases were positive for malaria, $44 \%$ cases were positive for typhoid and $5 \%$ cases were of co-infection (Table 4). There was no significant difference in monthly prevalence $(\mathrm{P}>0.05)$.

Table 4. Month wise prevalence \%

\begin{tabular}{llllllll}
\hline Months & $\begin{array}{l}\text { Total no. of } \\
\text { infected } \\
\text { sample (N) }\end{array}$ & $\begin{array}{l}\text { No. of } \\
\text { Malaria } \\
\text { infected } \\
\text { samples }\end{array}$ & $\begin{array}{l}\text { Prevalence } \\
\text { (\%) }\end{array}$ & $\begin{array}{l}\text { No. of } \\
\text { Typhoid } \\
\text { infected } \\
\text { sample }\end{array}$ & $\begin{array}{l}\text { Prevalence } \\
\text { (\%) }\end{array}$ & $\begin{array}{l}\text { No. of Co- } \\
\text { infected } \\
\text { sample }\end{array}$ & $\begin{array}{l}\text { Prevalence } \\
\text { (\%) }\end{array}$ \\
\hline Sep 2012 & 83 & 35 & $\mathbf{4 2 . 0}$ & 44 & $\mathbf{5 3 . 0}$ & 4 & $\mathbf{5 . 0}$ \\
Oct 2012 & 57 & 27 & $\mathbf{4 7 . 0}$ & 28 & $\mathbf{4 9 . 0}$ & 2 & $\mathbf{4 . 0}$ \\
Nov 2012 & 31 & 9 & $\mathbf{2 9 . 0}$ & 21 & $\mathbf{6 8 . 0}$ & 1 & $\mathbf{4 . 0}$ \\
Dec 2012 & 17 & 2 & $\mathbf{1 2 . 0}$ & 15 & $\mathbf{8 8 . 0}$ & 0 & $\mathbf{0 . 0}$ \\
Jan 2013 & 19 & 0 & $\mathbf{0 . 0}$ & 19 & $\mathbf{1 0 0}$ & 0 & $\mathbf{0 . 0}$ \\
Feb 2013 & 10 & 2 & $\mathbf{2 0 . 0}$ & 8 & $\mathbf{8 0 . 0}$ & 0 & $\mathbf{0 . 0}$ \\
Mar 2013 & 33 & 11 & $\mathbf{3 3 . 0}$ & 21 & $\mathbf{6 4 . 0}$ & 1 & $\mathbf{3 . 0}$ \\
Apr 2013 & 61 & 31 & $\mathbf{5 1 . 0}$ & 27 & $\mathbf{4 4 . 0}$ & 3 & $\mathbf{5 . 0}$ \\
\hline
\end{tabular}

\section{DISCUSSION}

This survey first time described the dual infection with malaria and typhoid in District Dir Lower. Malaria and typhoid is still a major public health problem in tropics. Due to the high prevalence of typhoid and malaria in the tropic coinfection are also common, but the mechanisms to explain the association between malaria and typhoid causing species is unknown (UKAEGBU et al., 2014). The prevalence of co-infection of malaria and typhoid parasite is very low. Because physician and clinicians are often compelled by the patient to prescribe an antimalarial drug or antityphoidal drug without doing any test of the disease (MBUH et al., 2003).

The prevalence of typhoid and malaria co- infection in District Dir Lower which is 4\% correlates with the finding of (AFOAKWAH et al., 2011). They found the prevalence of co-infection in Ghana which was $4.65 \%$. This similarity is due to the fact that in both areas the same diagnostic procedure is adapted. The Prevalence of typhoid and malaria co-infection in Sokoto-Nigeria was $1.33 \%$. The difference in the prevalence is due to the fact that in Sokoto instead of widal and typhidot test blood culture method is used which give accurate results as compare to widal and typhidot test (ALHASSAN et al., 2012).

In Owerri, the rate of co-infection with malaria parasite and Salmonella typhi is much higher. This variation from the prevalence of coinfection of typhoid and malaria in Dir Lower is due to the fact that resident of Owerri depends on 
borehole water which contains a lot of impurities. The situation is further worsened due to the poor sanitary system of Owerri. While in Dir Lower the sanitary system and water quality are of the good level (NWUZO et al., 2009). On the other hand, dry season and less rainfall can also minimize the rate of co-infection, because in which water is scarce and no accumulation of water in the gutter, bowls, leaves and the surrounding which act as a breeding site for this parasite (STOREY et al., 2015).

Salmonella typhi infection is common in Pakistan. The most affected group due to typhoid is children younger than 10 years (SIDDIQUI et al., 2006), which matching to our typhoid prevalence in which children have got more infection (60\%) than adult $(40 \%)$. So due to this high infection rate of typhoid in children the co-infection is also found more in children (55\%) than adult (45\%). And we saw that malaria is in greater rate in male than female there for the rate of co-infection is greater in male than female and it is because that in Dir Lower the males are more exposed to mosquitoes due to labor and working in fields and in the forest as compare to female. During our research period, we have noticed that, in the month of December, January and February the rate of malaria was very low, it is due to the fact that in these months in Dir Lower the season is much heard and cold and mosquitoes cannot adapt and bread in the result the malarial rate is very low.

\section{CONCLUSION}

Malaria and typhoid infections are very high in district lower Dir. While co-infected cases for both malaria and typhoid were low (4\%) of the total infection. Since both diseases have comparable symptomatology, treatment should be based on passable laboratory analysis. As both infections were misdiagnosed on the basis of symptoms without laboratory test. It is suggested that personal sanitation should also be encouraged among the general public in such areas. Further epidemiological investigations should be made on monthly and seasonal basis in relation to abiotic factors to develop control strategies of these infection in study area.

RESUMO: A malária e a febre tifóide estão entre as doenças mais endêmicas nos países tropicais e em desenvolvimento. Ambas as doenças compartilham fator de transmissão semelhante e muitas vezes têm sintomas semelhantes. Com base nessa razão, muitos profissionais da saúde tentam curar a malária e a febre tifóide ao mesmo tempo em cada caso de suspeita de infecção por Salmonella e vice-versa. O Distrito Dir (inferior) é um local favorável para a nutrição de protozoários e o segundo local com mais casos reportados de malária e co-infecções tifoides. O principal objetivo deste estudo foi descobrir a prevalência da malária e da coinfecção tifóide nos distritos de Dir (Lower), Khyber Pakhtunkhwa (KPK), Paquistão. As amostras de sangue de 1889 pacientes foram examinadas de setembro de 2012 a abril de 2013, das quais 311 (16,46\%) foram positivas para malária e febre tifóide. Destes infectados, 117 (38\%) amostras foram positivas para a malária, $183(58 \%)$ amostras foram positivas para a febre tifóide, enquanto os casos co-infectados foram apenas 11 (4\%). Os resultados atuais indicam que esta área é endêmica para malária e febre tifóide e co-infecção. Sua infecção é prevalente em ambos os sexos em diferentes graus.

PALAVRAS-CHAVE: Malária. Febre tifóide. Co-infecção. KPK.

\section{REFERENCES}

ACHONDUH-ATIJEGBE, O. A., MFUH, K. O., MBANGE, A. H., CHEDJOU, J. P., TAYLOR, D. W., NERURKAR, V. R., MBACHAM, W. F., LEKE, R. Prevalence of malaria, typhoid, toxoplasmosis and rubella among febrile children in Cameroon. BMC infectious diseases, v. 16, p. 658,2016.

https://doi.org/10.1186/s12879-016-1996-y

ACOSTA, C. J., DANOVARO-HOLlidAY, M. C., BAIQING, D., BHATTACHARYA, S. K., AGTINI, M. D., BHUTTA, Z. A., ALI, M., SHIN, S., WAIN, J., PAGE, A. L. A study of typhoid fever in five Asian countries: disease burden and implications for controls. World Health Organization. Bulletin of the World Health Organization, v. 86, p. 260,2008.

AFOAKWAH, R., ACHEAMPONG, D., BOAMPONG, J., SARPONG-BAIDOO, M., NWAEFUNA, E., 
TEFE, P. Typhoid Malaria Co-infection in Ghana. European Journal of Experimental Biology, v. 1, p. 1-6, 2011.

ALHASSAN, H., SHIDALI, N., MANGA, S., ABDULLAHI, K., HAMID, K. Co-infection profile of Salmonella typhi and malaria parasite in Sokoto-Nigeria. Global Journal of Science, Engineering and Technology, v. 2, p. 13-20,2012.

ARAFAT, M. Y., SOBUR, M. A., HAQ, M. A., ISLAM, M. N., 2014. Current Pattern in Antimicrobial Susceptibility in Enteric Fever in A Private Medical College. Bangladesh Journal of Medical Science, v. 13, p. 67,2014 . https://doi.org/10.3329/bjms.v13i1.17440

COLOMBA, C., SCARLATA, F., DI CARLO, P., GIAMMANCO, A., FASCIANA, T., TRIZZINO, M., CASCIO, A. Fourth case of louse-borne relapsing fever in young migrant, Sicily, Italy, December 2015. Mini Review Article Public Health, v. 139, p. 22-26, 2016.

CONNOR, B. A., SCHWARTZ, E. Typhoid and paratyphoid fever in travellers. The Lancet Infectious Diseases, v. 5, p. 623-628, 2005. https://doi.org/10.1016/S1473-3099(05)70239-5

CULLEN, K. A., ARGUIN, P. M. Malaria surveillance-United States, 2012. Morbidity and Mortality Weekly Report: Surveillance Summaries, v. 63, p. 1-22, 2014.

EKESIOBI, A. O., IGBODIKA, M. C., NJOKU, O. O. Co-infection of malaria and typhoid fever in a tropical community. Animal Research International, v. 5, 2017.

FAROOQUI, A., KHAN, A., KAZMI, S. U. Investigation of a community outbreak of typhoid fever associated with drinking water. BMC Public Health, v. 9, p. 476,2009. https://doi.org/10.1186/1471-2458-9-476

FERNANDES, A. A. M., DE MOURA CARVALHO, L. J., ZANINI, G. M., DA SILVA VENTURA, A. M. R., SOUZA, J. M., COTIAS, P. M., SILVA-FILHO, I. L., DANIEL-RIBEIRO, C. T. Similar cytokine responses and degrees of anemia in patients with Plasmodium falciparum and Plasmodium vivax infections in the Brazilian Amazon region. Clinical and Vaccine Immunology, v. 15, p. 650-658, 2008.

https://doi.org/10.1128/CVI.00475-07

HALLIDAY, J. E., ALLAN, K. J., EKWEM, D., CLEAVELAND, S., KAZWALA, R. R., CRUMP, J. A. One health: Endemic zoonosis in the tropics: A public health problem hiding in plain sight. The Veterinary Record, v. 176, p. 220, 2015. https://doi.org/10.1136/vr.h798

KEONG, B. C. M., SULAIMAN, W. Typhoid and Malaria Co-Infection-An Interesting Finding in the Investigation of a Tropical Fever. The Malaysian Journal of Medical Sciences: MJMS, v. 13, p. 74, 2006.

KOCHAR, D., DAS, A., KOCHAR, A., MIDDHA, S., ACHARYA, J., TANWAR, G., PAKALAPATI, D., SUBUDHI, A., BOOPATHI, P., GARG, S. A prospective study on adult patients of severe malaria caused by Plasmodium falciparum, Plasmodium vivax and mixed infection from Bikaner, northwest India. Journal of Vector Borne Diseases, v. 51, p. 200, 2014.

KREMSNER, P. G., ADEGNIKA, A. A., HOUNKPATIN, A. B., ZINSOU, J. F., TAYLOR, T. E., CHIMALIZENI, Y., LIOMBA, A., KOMBILA, M., BOUYOU-AKOTET, M. K., MBOUMBA, D. P. M. Intramuscular artesunate for severe malaria in African children: a multicenter randomized controlled trial. PLoS medicine, v. 13, e1001938, 2016. https://doi.org/10.1371/journal.pmed.1001938

LEVINE, M. M., GRADOS, O., GILMAN, R. H., WOODWARD, W. E., SOLIS-PLAZA, R., WALDMAN, W. Diagnostic value of the Widal test in areas endemic for typhoid fever. The American Journal of Tropical Medicine and Hygiene, v. 27, p. 795-800, 1978. https://doi.org/10.4269/ajtmh.1978.27.795 
MBUH, F. A., GALADIMA, M., OGBADU, L. Rate of co-infection with malaria parasites and Salmonella typhi in Zaria, Kaduna State, Nigeria, 2003.

MOGASALE, V., MASKERY, B., OCHIAI, R. L., LEE, J. S., MOGASALE, V. V., RAMANI, E., KIM, Y. E., PARK, J. K., WIERZBA, T. F. Burden of typhoid fever in low-income and middle-income countries: a systematic, literature-based update with risk-factor adjustment. The Lancet Global health, v. 2, e570-e580, 2014. https://doi.org/10.1016/S2214-109X(14)70301-8

NIIKURA, M., KAMIYA, S., NAKANE, A., KITA, K., KOBAYASHI, F. IL-10 plays a crucial role for the protection of experimental cerebral malaria by co-infection with non-lethal malaria parasites. International Journal for Parasitology, v. 40, p. 101-108, 2010. https://doi.org/10.1016/j.ijpara.2009.08.009

NWUZO, A., ONYEAGBA, R., IROHA, I., NWORIE, O., OJI, A. Parasitological, bacteriological, and cultural determination of prevalence of malaria parasite (Plasmodium falciparum) and typhoid fever co-infection in Abakaliki, Ebonyi State. Scientific Research and Essays, v. 4, p. 966-971, 2009.

ODIKAMNORO, O., IKEH, I., OKOH, F., EBIRIEKWE, S., NNADOZIE, I., NKWUDA, J., ASOBIE, G. Incidence of malaria/typhoid co-infection among adult population in Unwana community, Afikpo North local Government area, Ebonyi state, Southeastern Nigeria. African journal of infectious diseases, v. 12, n. 33, 2018.

ONIS, M. D., FRONGILLO, E. A., BLÖSSNER, M. Is malnutrition declining? An analysis of changes in levels of child malnutrition since 1980. Bulletin of the World Health Organization, v. 78, p. 1222-1233, 2000.

Organization, W. H. World health statistics 2010. World Health Organization, 2010.

RAFIQUE, N., IMRAN, A., KHAN, L. Identification of Plasmodium falciparum in anemic patients with special reference to pregnancy. Journal of Biodiversity and Environmental Sciences (JBES), v. 9, n. 2, p. 113-121, 2016.

RAO, C., SOWMYA, S. Malaria, Typhoid, blood culture, Typho Malarial co-infection. Malaria typhoid coinfection among febrile patients, 2015.

SIDDIQUI, F. J., RABBANI, F., HASAN, R., NIZAMI, S. Q., BHUTTA, Z. A. Typhoid fever in children: some epidemiological considerations from Karachi, Pakistan. International Journal of Infectious Diseases, v. 10, p. 215-222, 2006. https://doi.org/10.1016/j.ijid.2005.03.010

STOREY, H. L., HUANG, Y., CRUDDER, C., GOLDEN, A., DE LOS SANTOS, T., HAWKINS, K. A metaanalysis of typhoid diagnostic accuracy studies: a recommendation to adopt a standardized composite reference. PloS one, v. 10, p. e0142364, 2015. https://doi.org/10.1371/journal.pone.0142364

SULAIMAN, K., SARWARI, A. Culture-confirmed typhoid fever and pregnancy. International Journal of Infectious Diseases, v. 11, p. 337-341, 2007. https://doi.org/10.1016/j.ijid.2006.09.007

UKAEGBU, C., NNACHI, A., MAWAK, J., IGWE, C. Incidence of Concurrent Malaria and Typhoid Fever Infections in Febrile Patients in Jos, Plateau State Nigeria, 2014.

UNEKE, C. Concurrent malaria and typhoid fever in the tropics: the diagnostic challenges and public health implications. Journal of Vector Borne Diseases, v. 452, n. 133, p. 133-142, 2008.

WANG, S., JACOBS-LORENA, M. Paratransgenesis Applications: Fighting Malaria with Engineered Mosquito Symbiotic Bacteria, Arthropod Vector: Controller of Disease Transmission, v. 1. Elsevier, p. 219234, 2017. 
WONG, V. K., BAKER, S., CONNOR, T. R., PICKARD, D., PAGE, A. J., DAVE, J., MURPHY, N., HOLLIMAN, R., SEFTON, A., MILLAR, M. An extended genotyping framework for Salmonella enterica serovar Typhi, the cause of human typhoid. Nature communications, v. 7, 12827, 2016. https://doi.org/10.1038/ncomms 12827

WOODRUFF, A. W., WRIGHT, S. G. A synopsis of infectious and tropical diseases. ButterworthHeinemann, 2013.

YASINZAI, M. I., KAKAR, J. K. Prevalence of human malaria infection in bordering areas of Baluchistan with Sindh province: district Jaffarabad. Journal of Postgraduate Medical Institute (Peshawar-Pakistan) 26, 2012.

YASINZAI, M. I., KAKARSULEMANKHEL, J. K. Prevalence of human malaria infection in Pakistani areas bordering with Iran. Journal of Pakistan Medical Association, v. 63, p. 313-316, 2013.

ZAREEN, S., ZAREEN, H., ZAMAN, H., REHMAN, H. U., REHMAN, N. U., NAYAB, M., ISRAR, B., KHAN, F., WALI, N., AHMAD, R. Burden of Plasmodium vivax and Plasmodium falciparum in Afghan Refugee Camps located at Ghamkol Road Peshawar bypass District Kohat, 2016.

ZUREK, L., GHOSH, A. Insects represent a link between food animal farms and the urban environment for antibiotic resistance traits. Applied and Environmental Microbiology, v. 80, p. 3562-3567, 2014.

https://doi.org/10.1128/AEM.00600-14 